The Hymnographic Book of Tropologion

Sources, Liturgy and Chant Repertory

Svetlana Kujumdzieva 


\section{The Hymnographic Book of Tropologion}

The Tropologion is considered the earliest known extant chant book from the early Christian world, which was in use until the twelfth century. The study of this book is still in its infancy. It has generally been believed that the book has survived in Georgian translation under the name "ladgari," but similar books have been discovered in Greek, Syriac and Armenian. All the copies clearly show that the spread and the use of the book were much greater than we had previously assumed and the Georgian ladgari is only one of its many versions.

The study of these issues unquestionably confirms the earliest stage of the compilation of the book, in Jerusalem or its environs, and shows its uninterrupted development from Jerusalem to the Stoudios monastery, the most important monastery of Constantinople. Over time many new pieces and new authors were added to the Tropologion. It is almost certain that it was the Stoudios school of poet-composers that divided the content of the Tropologion and compiled separate collections of books, each one containing a major liturgical cycle. In the beginning, all of the volumes kept the old title but in the tenth century the copies of the book were renamed, probably according to the liturgical repertory included, and by the thirteenth century the title 'Tropologion' is no longer found in the Greek sources as it became superfluous, and fell out of use.

Svetlana Kujumdzieva is Professor of Medieval Music at the Bulgarian Academy of Sciences and also at the National Musical Academy and Theological Faculty of the Sofia State University "St. Clement of Ohrid." She has specialized in Byzantine and Slavic music at the Institute of Musicology, University of Hamburg (1986) and at the Dumbarton Oaks Center for Byzantine Studies, University of Harvard (1994). She has been an associate member of the John W. Kluge International Center, Library of Congress, Washington DC; of the Resource Center for Medieval Slavic Studies, Ohio State University, Columbus, OH; of St. John College, Oxford; and of St. Louis University in St. Louis, MO. She has published eight books and over 150 articles. 
This page intentionally left blank 


\section{The Hymnographic Book of Tropologion}

Sources, Liturgy and Chant Repertory

\section{Svetlana Kujumdzieva}

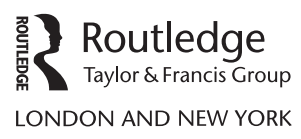


First published 2018

by Routledge

2 Park Square, Milton Park, Abingdon, Oxon OX14 4RN

and by Routledge

711 Third Avenue, New York, NY 10017

Routledge is an imprint of the Taylor \& Francis Group, an informa business

(C) 2018 Svetlana Kujumdzieva

The right of Svetlana Kujumdzieva to be identified as author of this work has been asserted by her in accordance with sections 77 and 78 of the Copyright, Designs and Patents Act 1988.

All rights reserved. No part of this book may be reprinted or reproduced or utilised in any form or by any electronic, mechanical, or other means, now known or hereafter invented, including photocopying and recording, or in any information storage or retrieval system, without permission in writing from the publishers.

Trademark notice: Product or corporate names may be trademarks or registered trademarks, and are used only for identification and explanation without intent to infringe.

British Library Cataloguing-in-Publication Data

A catalogue record for this book is available from the British Library

Library of Congress Cataloging-in-Publication Data

Names: Kujumdzieva, Svetlana, author.

Title: The hymnographic book of Tropologion: sources,

liturgy and chant repertory / Svetlana Kujumdzieva.

Description: Abingdon, Oxon; New York, NY: Routledge, 2018. |

Includes bibliographical references and index.

Identifiers: LCCN 2017025131 | ISBN 9781138297814

(hardback: alk. paper) | ISBN 9781315099019 (ebook)

Subjects: LCSH: Church music_-Orthodox Eastern Church |

Byzantine chants-History and criticism. | Orthodox Eastern

Church-Liturgy-History.

Classification: LCC ML188 .K88 2018 | DDC 781.71/15—dc23

LC record available at https://lccn.loc.gov/2017025131

ISBN: 978-1-138-29781-4 (hbk)

ISBN: 978-1-315-09901-9 (ebk)

Typeset in Times New Roman

by codeMantra 


\section{Contents}

List of illustrations $\quad$ vi

Abbreviations vii

Preliminary words viii

1 The Hymnographic Book of Tropologion - Perspectives of the study 1

2 The early sources 13

3 The Georgian Iadgari 30

4 The Syriac Tropligin $\quad 54$

5 The Greek Tropologion $\quad 74$

6 Was there an Old Slavic Tropologion? 123

7 Relics of Tropologion 134

8 The Tropologion in its historical transmission 145

$\begin{array}{ll}\text { Bibliography } & 157\end{array}$

Indexes 181 


\section{List of illustrations}

1 Manuscript Sinai 607, 9th century, f. 3r: the rubric reads that this is a Tropologion for two months - March and April

2 Manuscript Sinai 759, 9th century, f. 1r: the rubric reads that the book is a Tropologion starting with Palm Sunday and ending with the Sunday of All Saints

3 Manuscript Sinai 556, 11th century, f. 1r: the rubric reads that it is a Tropologion beginning with September 1, the "indiktion"

4 Manuscript Sinai 212, 7th to the 9th century, f. 1r. Gospel-Lectionary. In the middle is read "mode 1 authentikos"

5 Manuscript Vat. gr. 771, Tropologion, 11th century, f. 118v: below on the sheet is the first inscription of Nilus

6 Manuscript Vat. gr. 771, Tropologion, 11th century, f. 188v: below on the sheet is the second inscription of Nilus

7 Manuscript Vat. gr. 771, Tropologion, 11th century, f. 1v: chants by Leo VI the Wise in theta-notation

8 Manuscript Vat. gr. 2008 from 1102, Tropologion, f. $182 \mathrm{v}$ : theta-notation in stichera

9 Manuscript Vat. gr. 2008 from 1102, Tropologion, f. 185v: Coislin, Chartres and theta-notation

10 The Ilia's book, 12th century, f. 122v: the rubric below reads: "On Saturday first week of Lent" 


\section{Abbreviations}

BBGG Bolletino della Badia Greca di Grottaferrata

DOP Dumbarton Oaks Papers

EMH Early Music History

JL Jahrbuch für Liturgiewissenschaft

JAMS Journal of the American Musicological Society

JTS Journal of Theological Studies

MMB Monumenta Musicae Byzantinae

OCA Orientalia Christiana Analecta

OCP Orientalia Christiana Periodica

OC Oriens Christianus

OLA Orientalia Lovaniensia Analecta

ODB Oxford Dictionary of Byzantium

OHB Oxford History of Byzantium

OS Ostkirlichen Studien

PMM Plainsong and Medieval Music

PO Patrologia Orientalis

SL Studia Liturgica

SP Studia Patristica

VC Vigiliae Christiane

БЕ Български език

БМ Българско музикознание

Вp Византийский временник

ГСУ Годишник на Софийския университет

КМЕ Кирило-Методиевска енциклопедия

КМС Кирило-Методиевски студии

СЛ Старобългарска литература

СЛЕР Старобългарска литература. Енщиклопедичен речник 


\section{Preliminary words}

Many different kinds of hymnographic liturgical books survive from the early medieval period. They vary in language, content, hymnodic genre, principles of organization, presence or absence of music notation, liturgical rite or regional tradition, etc. As a whole our knowledge about them is very limited. The Tropologion is one of the books that contain hymns for the Christian worship performed in the early Eastern Church. It is a central subject in the study of the origins of the early hymnographic liturgical books. The author's focus is on this book as a book type. The goal is to present manuscripts that have been called Tropologion, and the hymnographic sources related to the latter. Manuscripts in Greek, Syriac, Georgian and Armenian entitled, respectively, "Tropologion," "Tropligin," "Iadgari" and "Šaraknoc" are discussed. Hence, the designation "Tropologion" is used here as a collective term for all the early hymnographic books bearing these designations. In addition, some of the early Old Slavic books that reveal characteristics related to the book of the Tropologion are included.

The present study is based on both original source material and secondary literature that was published until now and is related to the topic. The critical approach to previous studies that seek to understand the Tropologion in its old and new forms is refreshing, since this book insists on studying the extant manuscripts of the Tropologion, limiting the amount of speculation that can be made about earlier periods for which no texts or source material have been preserved. In this sense, the topic is of great importance to the early hymnographic books, to the sources preserved, to their liturgy and chant repertory.

Two issues should be stressed. First, the author has worked with primary sources in Greek and Slavic only: primary sources in the other three languages are discussed on the basis of secondary sources, that is, manuscripts are consulted from catalogues and not through direct examination and study. That is why some descriptions of the manuscripts presented are longer than the other. Second, the discussions and comparisons of manuscripts are not based on the actual content of the hymns they contain. The concrete analysis of the text is not a research goal in this book. Such an analysis suggests a special philological knowledge and relevant studies, 
which are outside the specialization of the author. The centre of research are three basic parameters: the arrangement of the repertory, the genres included and the liturgical calendar according to which the offices are organized. The sources discussed are described and compared according to these parameters. This book could be considered as a propaedeutic step of collected manuscript sources in the further comprehensive and thorough study of the Tropologion.

It is my great pleasure, finally, to express my deepest gratitude to all the colleagues and institutions that supported this project. It could not have been accomplished if I had not had the rare chance to work with the rich literature of the Library of Congress in Washington, DC twice, during my association as a Fellow at the international John W. Kluge Center in 2003/2004 and 2009/2010. My deep gratitude goes out to all the colleagues from the Center's administration, especially to its two directors during my stay there, Dr Prosser Gifford and Dr Carolin Brown, who provided excellent conditions for my research. I also want to extend my gratitude to Dr Alice-Mary Talbot and Dr Margaret Mullett, directors of Byzantine Studies at the Dumbarton Oaks Center of Harvard University, who provided access to work in this unique Center during my stay in Washington, DC. I owe further thanks to the administration of the Vatican Film Library at St. Louis University in Saint Louis, Missouri, USA, and especially to its director, Dr Gregory Pass, and Dr Susan L'Egle, the editor-in-chief of the Manuscripta journal, where I also had the opportunity to do research work twice - in 2003/2004 and 2012. Especially deep is my gratitude to the late professor Miloš Velimirović (+2008), professor Ruth Steiner and professor Barbara Hagh-Huglo, who supported my project as my reviewers. My discussions with them were of utmost importance. To all of them - my gratitude and deep respect! 
This page intentionally left blank 


\section{The Hymnographic Book of Tropologion - Perspectives of the study}

In 1980 the Georgian scholars E. P. Metreveli, C. A. Chankieva and M. Hevsuriani published a fundamental study with the texts of seven copies of a very early hymnographic book with non-biblical material known in Georgian under the name Iadgari. ${ }^{1}$ The publication was epoch-making because - as the Georgian scholars claimed - Iadgari was the oldest hymnographic book that came to us, presenting the worship in one of the most important legislative centers in the field of early Christian worship in the East in the time up to the ninth century - Jerusalem. The publication of the Georgian scholars' work is in Georgian and until now there is no translation of the Georgian liturgical texts in any other language, which makes their study difficult. Fortunately, there are two large summaries in French and in Russian at the end of the book, and it is due to them that the results of the research are accessible to the wider international scientific audience. All the copies of the book are from the tenth century. However, the material included - in terms of the festal calendar, the order or the structure of the repertory and genres - goes back to the fifth century, which is a much earlier time than that of their writing. ${ }^{2}$ Six manuscripts are from the library of St. Catherine's monastery on Mount Sinai: Sinai Georgian 18, 20, 26, 34, 40 and 41; one manuscript is from Tbilisi: H-2123. The manuscripts 18,40 and 41 are considered to have been written slightly earlier than 20, 26, 34 and H-2123. ${ }^{3}$ According to the Georgian scholars the Greek model of Iadgari should have been the Tropologion. ${ }^{4}$ The latter was the universal hymnographic book that was used in Jerusalem churches between the seventh and ninth centuries, according to the Jerusalem Typikon of that time. ${ }^{5}$ The book went out of use after the twelfth century. Its basic core was composed of chants of the immovable and movable cycles and also chants of the weekday cycle, resurrectional and penitential in eight modes. The latter cycle, according to the Georgian scholars, presents the earliest Oktoechos and was included in its content a little bit later. ${ }^{6}$ The Georgian scholars distinguished between two main layers in the book that were organically linked. They call the first one "old." It is composed of psalms and troparia by anonymous authors from the fifth to the seventh centuries. This layer was not older than the seventh century. The second layer is referred to as "new." It 
is composed of stichera and kanons by authors from the seventh through the ninth centuries such as Germanos Patriarch (ca. 630/650?-730/742?), John of Damascus (ca. 650 - before 754), Kosmas of Maiuma/of Jerusalem (ca. 675-752), etc. ${ }^{7}$ The development of the book - according to the Georgian scholars again - progressed in two directions: first, by extending the range of the feasts, and second, by extending the feasts with new works and genres, mostly stichera and kanons.

The Georgian scholars emphasized that the Greek-language model regarding the structuring of the composition of the Georgian Iadgari was not found. In terms of the chants included in the Iadgari, they found 5 percent common chants between preserved copies of this book and various liturgical books in Greek. Here I will only say that recently a Tropologion in Greek of the Iadgari type was found and the number of common chants between this book and the modern liturgical books turned out to be above 50 percent (see further). ${ }^{8}$ The Georgian scholars further found that the chants in the Iadgari were accurate translations from the chants in Greek. The scholars concluded that the oldest form of the Iadgari went through various modifications and if the earliest layers of the book go back to the fifth century, the later ones that are found in the Sinai Georgian 26 and 34 manuscripts show that the book was constantly updated. ${ }^{9}$ For instance, a memory for St. Abo, a Georgian saint from the end of the eighth century (died in 786), was included in last two quoted manuscripts. ${ }^{10}$ In these, and also in Sinai Georgian 20, an early form of Heirmologion was found, specifically the incipits of heirmoi from kanons by Kosmas of Jerusalem and John of Damascus in eight modes. ${ }^{11}$ The manuscript Sinai 34 was compiled by the renowned tenth-century Palestinian monk John Zosime. Its compilation lasted several years: it started in St. Sabas monastery near Jerusalem and ended during the third quarter of the same century in 965. John Zosime was a writer of many other Georgian manuscripts housed in both St. Sabas and St. Catherine monasteries on Mount Sinai. The latter followed the tradition of the Holy City. Zosime was the first to indicate memories for every day of weekly worship: until him the weekdays had not been associated with a particular memory in written sources. Zosime reported the following weekly memories: Sunday, resurrectional day - the day of the Holy Resurrection; Monday and Tuesday - days of repentance; Wednesday and Friday - days of the Holy Cross; Thursday - the day of the Virgin Mary; and Saturday - the day of the saints and souls. ${ }^{12}$ Hence, it is clear that the core of the modern weekly cycle with determined memories for each day of the week must have been formed in about the tenth century. A slightly earlier source, the manuscript Sinai 863 (a Book of the Hours from St. Sabas monastery representing an early Jerusalem monastic liturgical Typikon), confirms this. ${ }^{13}$ It is also confirmed by the earliest manuscript in the eight-mode consecutive order for weekly worship, Sinai Greek 776, which along with two other manuscripts, Sinai 1593 and London British Add. 26, dated by Boris Fonkich from the first half of the ninth century, are considered the earliest manuscripts 
known later under the name Paraklitike or "Great Oktoechos" (containing the weekly liturgical cycle). ${ }^{14}$ The memories in this manuscript (Sinai 776) are not yet defined and fixed in the order of weekdays from Monday through Saturday, and the days are also not given by their names, as it is in all other manuscripts from the tenth century onwards. ${ }^{15}$

Among the main characteristics of the book that are pointed out by the Georgian scholars, an important note should be stressed. The festal calendar is very early: it was found in Georgian sermons of the fifth and sixth centuries. This conclusion confirms that the roots of the Tropologion date back to this early time. ${ }^{16}$ The Iadgari starts with the Annunciation, which is given on March 25 and is put before Christmas on December 25. The Annunciation, as a separate feast, is not encountered in some of the oldest sources representing the liturgical practice in Jerusalem - the Diary of the nun Egeria (also known as Eteria or Sylvia) from the end of the fourth century and the Armenian Lectionary from the first half of the fifth century (for these sources, see next chapter). The oldest reference of the Annunciation celebrated in Jerusalem worship was found in a homily of Patriarch Sophronios of Jerusalem (550-638) from the first half of the seventh century. ${ }^{17}$ This fact provided grounds for the conclusion that the Iadgari was one of the very earliest liturgical books. It documents the great feast of the Virgin Mary, the Theotokos, as occurring around Christmas - a very old liturgical practice that goes back to at least the fifth century. ${ }^{18}$ The feasts according to the Menaion and Triodion cycles follow an uninterrupted order of the church calendar. The yearly liturgical cycle runs from December through November. The immovable feasts run up to February 2, the Hypapante or the Purification; they are followed by the movable cycle up to April 23, the feast of St. George; and after that date the immovable festal cycle returns. In the last sections of the Iadgari, resurrectional and penitential chants for the weekly cycle are included in eight modes. In each mode, they are given in the succession of the offices: for Vespers, Orthros and the Liturgy. Kathismata and hypokoai that are performed in all of the feasts during both the yearly and weekly cycles are given as a separate section. ${ }^{19}$ In addition to these two genres, prokeimena with verses, alleluaria, stichera and kanons are also included. The Georgian scholars pay special attention to the kanons. They stress that the kanons are the main hymnographic form in the two large sections in the Iadgari: those of the Menaion and the Triodion. There are both full kanons, with nine odes, and incomplete ones, composed of two, three and four odes. Twenty-five of them are full kanons for the feasts of the Lord, for the great church feasts and for the common services. All of them have a second ode. There are two kanons for most of the services. The second kanon is designated as "other" ( $\left.\alpha \lambda \lambda \alpha^{\prime} \varsigma\right)$. That the kanons in the Iadgari are very old is proven by the fact that in the book they are still very closely related to the Biblical odes, which means that many kanons, especially those designated as "other," do not have a heirmos. In other words, their first strophe is not related thematically to the other strophes, respectively, which 
means that it does not determine their melody and rhythm. Also, the ninth ode of the kanons is not designated as theotokion, that is, it is not intended for the praise of the Virgin Mary yet. ${ }^{20}$

The results of the Georgian scholars' research are discussed in many publications by Andrew Wade, ${ }^{21}$ Peter Jeffery, ${ }^{22}$ Maya Momina, ${ }^{23}$ Gabriele Winkler, ${ }^{24}$ Hans-Michael Schneider, ${ }^{25}$ Olga Krasheninnikova, ${ }^{26}$ Stig Simeon Frøyshov ${ }^{27}$ and others. All of them point out that the Georgian Iadgari is the oldest hymnographic book and as it was the only Georgian translation that survived, that is how the book came to us. The Greek prototype of the book is the Tropologion. The Iadgari actually presents a full Jerusalem Church Tropologion, containing chant texts for the whole church year: for the feasts of saints, Lent, Easter and post-Easter time, as well as for the resurrectional and common services. The book emerged as a result of recording troparia used in the worship. The name Tropologion comes from the main genre included in the book - a book with collected troparia. The troparia are called dasadebeli in Georgian. The term "Tropologion" was known by both generations - of John of Damascus in the Sabas monastery and of Theodore the Studite (759-826) in the Studios monastery in Constantinople. ${ }^{28}$

Scholars agree that the book was known only in its Georgian translation under the name Iadgari. ${ }^{29}$ The translation was done from Greek into Georgian. In Georgia, which is not far away from Jerusalem, worship was adopted from the Holy City in the same way it was practiced there in the seventh and eighth centuries. The Jerusalem worship was preserved in the Iadgari in its "purist" form. ${ }^{30}$ According to Peter Jeffery, the Iadgari was the first attempt to write down what had previously existed only in the minds of singers; this happened by the end of the sixth or in the seventh century. ${ }^{31}$ In earlier times there was only one universal liturgical hymnographic book - the Tropologion. ${ }^{32}$ Most likely in the eighth or in the beginning of the ninth century, due to the increased festive repertory included in it, the hymnographic material began to split into separate collections corresponding to the three major sections of the Tropologion. This marked the beginning of the modern liturgical books - the Menaion, Triodion and the Oktoechos. ${ }^{33}$ The Tropologion as a type of book ceases to exist after the separation of its repertory and the compilation of the latter in separate individual types of books. Here I will only say that of all modern liturgical books, the notated full Sticherarion (composed of the Menaion, Triod-Pentekostarion and Oktoechos) is the closest to it in terms of its structure notwithstanding some differences.

The two separate layers in the Iadgari, referred to by the Georgian scholars as "old" and "new," were interpreted further and put into some chronological frames. Some recent studies in this respect belong to the Norwegian scholar Stig Simeon Frøyshov. ${ }^{34}$ In his research, he included the new finds from the library of St. Catherine's monastery on Mount Sinai discovered in 1975 by the archimandrite Sophronios and the monk Damianos during the renovation of one of the rooms in the monastery. ${ }^{35}$ According to 
Frøyshov, the development of the Tropologion/Iadgari (he calls the book "Hymnal," as well) went through two major stages. This is evidenced by the above-mentioned manuscript Sinai Georgian 34 from the tenth century: John Zosime has marked the "old" and the "new" repertory in it. The two designations gave reason for Frøyshov to build his hypothesis of the existence of an "ancient" Iadgary/Tropologion and of a "new" one. The "ancient" Iadgari/Tropologion was known in Georgian only. It was identified according to the old layers determined in the copies of the Georgian Iadgari. The translation was done in Georgian before 638, that is, before the Islamic period and the death of Patriarch Sophronios. ${ }^{36}$ Hence, according to Frøyshov's hypothesis, the "old" Iadgari/Tropologion was available between the fourth and the sixth centuries and was the oldest Christian collection of hymns, preserved in Georgian only. A separate copy of this book has not survived. The number of immovable feasts was still limited in the book. The common services - for martyrs, hierarchs, etc. in the eight modes - prevailed. In terms of its liturgical calendar, structure and rubrics, the "old" Iadgari corresponded to the Georgian Lectionary (see next chapter about the latter). The "new" Iadgari/Tropologion existed in Greek, Georgian and Syriac; some of its fragments were also in Palestino-Syriac. ${ }^{37}$ Frøyshov suggests that the process of compiling the "new" Iadgari began as early as the seventh century and most likely in its first half. According to him, the first hymnographer of the "new" Tropologion was Patriarch Sophronios of Jerusalem. His successors were John of Damascus and Kosmas of Jerusalem, whose flourishing time was the first half of the eighth century. The formation of the "new" Tropologion lasted at least until the tenth century. It is evidenced by the inclusion of the memory of the late eighth-century Georgian St. Abo in the book. Frøyshov concludes that the Georgians had translated the "old" Tropologion from Greek and continued to update the book even after the hymnographic reform made by John of Damascus and his generation; this occurred during the seventh and eighth centuries and would include their additions to the book, though not immediately. ${ }^{38}$ Frøyshov also suggests that there were elements of a third archaic stage in the book. He does not consider it, but summarizes that the three stages were closely related to each other and represented different stages in the development of the Jerusalem Book of Hours. ${ }^{39}$ Differences between them were revealed in terms of the layers of hymnody and available rubrics. In terms of their repertory, however, they were very close since a large part of this repertory was common. Frøyshov calls the "old" Tropologion "global," meaning that it contained both the yearly (immovable and movable) cycle and the weekly one. He stresses that such a "global" repertory has not been found in the "new" Tropologion in Greek, that is, the "new" Tropologion did not contain the yearly and weekly cycles together but separately. ${ }^{40}$

Whether there was an "old" Iadgari/Tropologion still remains disputable because the study of the Orthodox notated sources shows that they are constantly updated: up to the nineteenth century, pieces are systematically 
marked as to which of them are "old" or "new"; there are also indications of who the "old" authors and "new" authors were. Hence, until the discovery of a book containing repertory up to the seventh century only, the existence of an "old" Tropologion will remain questionable. It is very likely that the available copies of the Iadgari, which without doubt are translations from Greek originals, have been compiled in the way that we know them - with both old and new repertories. The compilation may have happened as early as the eighth century: the newest material in the book belongs to this time. In other words, the Tropologion was compiled in the eighth century and included the hymnographic material that was only practiced and transmitted orally until that time.

Among the issues discussed by scholars related to the Iadgari/Tropologion were also those concerning when and how the book emerged, what its composition was like, what genres were included, and so on; these are issues that will be discussed further.

Studies in recent years testify that books with collected non-biblical hymnic repertory from the early Christian time, such as the Iadgari-type, had a much wider dissemination and use than was previously thought. The Georgian Iadgari is just one version and, as we shall see, it was not only this book that contained hymnic material. ${ }^{41}$ For instance, as pointed out by Gabriele Winkler, a book called Šaraknoc was compiled at the beginning of the eighth century in Armenia. It is considered analogous to the Georgian Iadgari. ${ }^{42}$ Like the Iadgari, it includes a non-biblical hymnic repertory and it represents the oldest collection of troparia in eight modes in Armenian. The book is named after the major chant form included in it - sarakan, which corresponds to both the Greek troparion and the Georgian dasadebeli. ${ }^{43}$ Winkler establishes a close link between the toposes of the Georgian Iadgari and the Armenian Šaraknoc. ${ }^{44}$ She pointed out a connection between some of the toposes in these two books and their Syriac predecessors that went back to the first half of the fourth century. ${ }^{45}$ As stated by the researcher, the Armenian ritual in the greater part of its daily worship displayed the oldest form of the cathedral service connected with Jerusalem. There were clues from several liturgical layers of this ritual that came primarily from Syria. ${ }^{46}$ Hence, the Tropologion existed not only in Greek, Georgian, Syriac and Syro-Palestinian, as Frøyshov concludes, but also in Armenian (in its "old" layer). Winkler's studies support the above-mentioned thesis that the formation of one of the main hymnographic liturgical books (or of its major parameters), the Oktoechos, might have referred to Syria. ${ }^{47}$ This would make the Antioch-Syrian-Palestinian region one of the most likely places where the early Oktoechoi were both compiled and spread from.

A book closely related to the Georgian Iadgari and the Armenian Šaraknoc was found in Syriac manuscripts as well. The book is called in Syriac Trwplygyn. Numerous copies of this book are kept in the British Museum in London. They were written at the same time as the Georgian and the Armenian manuscripts - between the ninth and the twelfth centuries. ${ }^{48}$ 
The Syriac Tropligin contains non-biblical material as well. The main genre included in it and corresponding to the troparion is called maneyato (ma'nyotho). ${ }^{49}$ The study of this book supports Frøyshov's opinion that a Tropologion-type book from its early period was preserved in the Syriac translation as well. At the same time, it refutes the opinion of other scholars that such a book had only ever existed in Georgian. ${ }^{50}$

My interest in the problems related to the Tropologion and, respectively, to the Iadgari, was provoked during my work on the early Oktoechoi. I had set myself the task of investigating all the early Greek liturgical Sinai manuscripts until the thirteenth century in order to find the "roots" of the book of the Oktoechos, since scholarly opinions about its origins differ. The Sinai collection, as it is already well known, is unique in the context of the early Greek liturgical manuscripts - it does not have any parallel. The Sinai manuscripts are one of the best sources for research on the early hymnography and liturgy in some of the oldest and most important literary centers in the East St. Sabas monastery near Jerusalem, St. Catherine's monastery on Mount Sinai and the Studios monastery of St. John Prodromos in Constantinople. What I found during my study of the early Menaia, Triod-Pentekostaria and the Oktoechoi was amazing and it exceeded any and all expectations. In particular, studying three major parameters - the festal calendar, compilation and structure of the books, and genres - confirmed some of the conclusions about the Iadgari/Tropologion, but not all of them. The results of this study were published in my book, The Early Oktoechoi: Sources, Liturgy and Chant Repertory (Based on the Sources until the 13th Century). ${ }^{51}$ The focus of this research is placed on the book of the Tropologion in its versions in various languages. Some new sources have been added, including Slavic ones, and recent literature on the problem is discussed critically. The author is convinced that only in the broadest possible context of sources and documents involved in the study could be objectively ascertain the characteristics of the research object. It is not enough to draw general conclusions about a single manuscript without placing it within a broader research context (see further). ${ }^{52}$ It is necessary to view the entire evolution of any given book, along with its genealogy, and all the stages it has gone through, respectively, in its transmission as a type of book. As it is well known, there are no two identical manuscripts: in the early period (at least until the twelfth century), manuscripts vary greatly - they reflect various and diverse practices. The coexistence of various liturgical practices is characteristic to the time up to the thirteenth century. This is evidenced by multiple versions of different Typika used in different places. Hence, it is important to keep in mind how a given manuscript was perceived as a type of book by its contemporaries in the environment in which it was compiled and used. We don't know very much about the early hymnographic books. It would be 
better to disregard our later knowledge about them in order to objectively characterize their development and transmission. Otherwise, we are in danger of being biased in drawing conclusions regarding the stages of development of a given type of book. In other words, the methodological position of this study is to investigate the book of the Tropologion in its development and transmission as a type of book - the book that is designated as a Tropologion. This designation was kept by the contemporaries that used this book. We read it in its initial rubrics where it usually indicated the book type. The designation "Tropologion" ceased to exist when the new types of books were established. The study of liturgical books until the nineteenth century (I have in mind the notated books) implicitly indicates that the new type of book replaced the old one when the former was fully completed and accomplished. That is why a large number of early sources in different languages (Greek, Georgian and Syriac) are included here, designated as "Tropologion," "Iadgari" and "Tropligin." Also, "Šaraknoc" in Armenin, as well as sources showing some relation to this type of book are discussed. Additionally, various Menaia, Triodia and Oktoechoi from the period until the thirteenth century, in which the repertory of the Iadgari/Tropologion happened to be later distributed, are studied. The three main parameters that I have pointed out above are the focus of the research. A thorough study of them confirmed an earlier compilation of the book, contextualized its transmission between the time of the fifth/sixth and thirteenth centuries, and showed its spread throughout the Byzantine world, especially from Jerusalem to Constantinople and beyond. The book could have been compiled in a literary center either in Jerusalem or in a region that belonged to it. The most probable such center could have been the St. Sabas monastery. This was the most important legislative liturgical center in the East almost until the ninth century.

The main research goals of the work are the following: to collect the available copies of the Tropologion and to identify the repertory included in them; to trace the development of the compiled repertory in terms of the liturgical calendar, liturgy and genres; and to point out what remains as traditional in the book and what enters it as something new. One of the main issues in looking for the answers is whether the book itself has been modified as a whole, and if so, what happened to its entire included repertory when it went out of use. The concrete research tasks are connected with the above-mentioned research goals, namely to bring into prominence and to present the available copies of the book in Georgian, Syriac, Greek and Slavic; to consider them in the context of various Typika that were in use until the thirteenth century; and to display the specifics of the book's typology, considering its chronological transmission in the time up to the thirteenth century. It should be stressed again that the textual analysis, that is, the concrete analysis of the text of the book's copies, is not a research goal here. Such an analysis suggests a special philological knowledge and relevant studies, which are outside the specialization of the author. 
In Bulgarian medieval science, the book of the Iadgari/Tropologion is almost completely unknown. The study of both this book and the problem about the oldest hymnographic books is of significance to the early history of Old-Bulgarian culture. The Bulgarian sources preserved from the time until the thirteenth century are very few in number, and they are mostly fragments. The period from the ninth to the eleventh centuries was very poor in terms of preserved Bulgarian sources. Such sources are known from the thirteenth century onwards but they are in Cyrillic, the alphabet that was accepted after the Glagolitic alphabet in Bulgaria and replaced it. The thirteenth century was a time when the book of the Tropologion had already gone out of use. A book with the designation "Tropologion" in Bulgarian is not known. That does not mean that such a book never existed in Bulgaria, if we keep in mind the wide distribution of this book in the East, on the one hand, and on the second, that Bulgaria was the first Slavic country in the East to accept Christianity in $863 / 4$, and that the first liturgical books in Slavic were spread from Bulgaria. The study of typologically similar hymnographic manuscripts in Greek, Georgian and Syriac from the eight/ninth to the thirteenth centuries could shed light on the earliest Old-Bulgarian period in terms of the existence of these books. Therefore, the actuality of the topic about the Tropologion, especially for Bulgarian science, could be seen here to provide material for reconstructing the history of hymnography related to the time just before the activity of the two brothers, St. Cyril the Philosopher (826/7?-869) and St. Methodios (ca. 815-885). We do not know very much about this period.

\section{Notes}

1 Metreveli, E. P., C. A. Čankieva, and L. M. Hevsuriani. Udzvelesi Iadgari. Tbilisi, 1980 [Метревели, Е. П., Ц. А. Чанкиева, Л. М. Хевсуриани. Древнейший иадгари. Тбилиси, 1980].

2 Metreveli, E. P. Op. cit. ..., p. 923; Jeffery, P. The Sunday Office of Seventh Century Jerusalem in the Georgian Chant Books (A Preliminary Report). $S L, 21,1991,52-75$; idem. The Earliest Oktoechoi: The Role of Jerusalem and Palestine in the Beginning of Modal Ordering. In: The Study of Medieval Chant: Paths and Bridges. East and West. In Honor of Kenneth Levy. Ed. by P. Jeffery. Cambridge, 2001, 147-211; Renoux, C. Jerusalem dans le Caucase: Anton Baumstark verified. OCA, 265, 2001, 305-321.

3 The six Georgian manuscripts determined to be "liturgical" in the Checklist of K. Clark are dated as follows: N 18 - about the tenth and the thirteenth centuries; N 20-987; N 26-954; N 34-932; N 40 - about the tenth century; and N 41 the tenth century, see Clark, K. Checklist of Manuscripts in the St. Catherine's Monastery Mount Sinai. Washington, DC, 1952, pp. 19-20.

4 Charles Renoux stresses that he prefers using the terms hymnal and hymns instead of Tropologion as Elena Metreveli has translated the name of Iadgari, because the Tropologion refers to a later Byzantine liturgical book that appears for the first time during the activity of Theodore the Studite (759-826), crf. Schneider, H.-M. Lobpreis im rechten Glauben. Die Theologie der Hymnen an den Festen der Menschwerdung der alten Jerusalemer Liturgie im Georgischen 
Udzvelesi Iadgari. In: Studien zur alten Kirchengeschichte, 23, Borengasser-Bonn, 2004, S. 7.

5 Metreveli, E. P. Op. cit., pp. 921, 924.

6 Ibidem, p. 923.

7 Ibidem, pp. 923-925.

8 Nikiforova, A. The Tropologion Sin. gr. NE/MГ 56-5 of the Ninth Century: A New Source for Byzantine Hymnography. Scripta \& E-Scripta, 12, 2013, 157-185 (p. 182).

9 The two manuscripts were compiled by John Zosime in the tenth century, see Крашенинникова, О. А. Древнеславянский Октоих св. Климента архиепископа Охридского. По древнерусским и южнославянским спискам XIII-XV веков. Москва, 2006, с. 300.

10 This is the only Georgian saint included in the Iadgari. His memory is celebrated on January 7, the second day of the Epiphany, see Schneider, H.-M. Op. cit., S. 265.

11 Бруни, А.-М. Древнеславянский ирмологий и гимнографические традиции Святой земли: к вопросу о произхождении византийского прототипа. In: Jews and Slavs. Vol. 20. Jerusalem-Sofia, 2008, 301-316 (c. 307-308).

12 According to Крашенинникова, О. А. Цит. съч., с. 301.

13 Ibidem.

14 Stig Frøyshov determines this manuscript to be a Tropologion, probably written in Sinai according to C. Hannick, see Frøyshov, S. S. Greek Hymnody. In: The Canterbury Dictionary of Hymnology. Ed. by J. R. Watson and E. Hornby. Norwich, 2013, p. 33.

15 See Куюмджиева, С. Отново за ранните осмогласници: какво ни казват синайски грьцки рькописи 1593 и 776. Старобългарска литература, 37-38, 2007, 26-48; about these manuscripts see Куюмджиева, С. Ранните осмогласници. Извори, богослужение и певчески репертоар (по ръкописи до XIII в.). София, 2013, c. 118-129. See also the quoted literature there.

16 See Schneider, H.-M. Op. cit., S. 10.

17 Ibidem, S. 163.

18 Jeffery, P. The Sunday Office..., p. 57.

19 Metreveli, E. P. Op. cit., p. 925.

20 Ibidem, pp. 926, 928.

21 Wade, A. The Oldest Jadgari. The Jerusalem Tropologion, V-VIII Century. OCP, 50, 1984, 451-456.

22 Jeffery, P. Jerusalem and Rome (and Constantinople): The Musical Heritage of Two Great Cities in the Formation of the Medieval Chant Traditions. In: Cantus Planus. Budapest, 1980, 163-175; Jeffery, P. The Sunday Office...; Jeffery, P. The Earliest Oktoechoi...

23 Момина, М. О произхождении греческой триоди. Палестинский сборник. Вып. 28. Москва, 1986, 112-121.

24 Winkler, G. Die Licht-Erscheinung bei der Taufe Jesu und der Ursprung des Epiphaniefestes. $O C, 78,1994,177-229$.

25 Schneider, H.-M. Op. cit.

26 Крашенинникова, О. Древнеславянский октоих....

27 Frǿyshov, S. S. R. The Early Development of the Liturgical Eight-Mode System in Jerusalem. St. Vladimir's Theological Quarterly, 51, 2-3, 2007, 139-178.

28 Triodion und Pentekostarion nach slavischen Handschriften des 11.-14. Jahrhunderts. Herausg. von M. A. Momina, and N. Trunte. Paderborn, München, Wien, and Zürich, 2004, S. 44.

29 Jeffery, P. The Lost Chant Tradition of Early Christian Jerusalem: Some Possible Melodic Survivals in the Byzantine and Latin Chant Repertories. EMH, 11, 
1992, 151-190 (p. 158); Winkler, G. Das Sanctus. Über den Ursprung und die Anfänge des Sanctus und sein Fortwirken. $O C A, 267,2002$, p. 244.

30 Jeffery, P. The Earliest Oktoechoi..., p. 197.

31 Jeffery, P. The Sunday Office..., p. 53.

32 Момина, М. О произхождении...

33 Triodion und Pentekostarion..., S. 46.

34 Frøyshov, S. S. R. The Early Development..., pp. 143-144; Frøyshov, S. S. R. Greek Hymnody..., p. 20 and next.

35 Gehin, P. and S. Frøyshov. Nouvelles decouvertes sinaitiques: a propos de la parution de l'inventaire des manuscrits Grecs. Revised English Bible, T. 58. Paris, $2000,167-184$. The new finds refer to 55 papyruses, 1148 parchments (836 in Greek; rest of them - in Georgian, Old Slavic, Arabic, etc.) and 20 incunabula, see also Никифорова, А. Ю. “Сокрытое сокровище”. Значение находок 1975 года на Синае для истории Минеи. В: Гимнология. Т. 6. Москва, 2011, 8-31.

36 Gehin, P. and S. Frøyshov. Op. cit., p. 169.

37 Frøyshov, S. S. R. The Early Development..., p. 144.

38 Ibidem.

39 Frøyshov, S. S. Greek Hymnody.... III. Hymnody of the Rite of Jerusalem, p. 18.

40 Ibidem, p. 31.

41 See Куюмджиева, С. Проучвайки ранните осмогласници: нови данни. In: KMC, 17, 2008, 453-464; also: Kujumdzieva, S. In Searching for the Earliest Oktoechoi: The Book of the Tropologion. In: Musica Antiqua Europae Orientalis, XIV. Bydgoszcz, 2006, 55-65.

42 Winkler, G. Der armenische Ritus: Bestandsaufnahme und neue Erketnisse sowie eine kürzere Notizen zur Liturgie der Georgier. OCP, 251, 1996, 265-298. The oldest compilation of the Šaraknoc was found in a manuscript from the end of the twelfth century, Matenadaran 9838 from 1193. The repertory included in this manuscript starts with Christmas on January 6, see Winkler, G. Das theologische Formelgut über den Schöpfer, das omoou/sioj, die Inkarnation und Menschwordung in den georgischen Troparien des Iadgari im Spiegel der christlich-orientalischen Quellen. $O C, 84,2000,117-178$. C. Renoux considers the Armenian Saraknoc as an analogue of the Georgian Iadgari as well, see Renoux, C. Jerusalem dans le Caucase..., 305-321.

43 A. Arevshatian quotes a troparion with the designation "kzurd." This troparion appeared in the fifth century. It represented the short, independent chant of psalmodic type that followed the psalms. The text of this troparion was both a paraphrase of various biblical episodes and acts of Christ's life. The kzurds are the base of Šaraknoc, the Armenian liturgical chant book. In the early manuscripts from the fifth to the seventh centuries, the designation kzurdaran is encountered. The latter refers to both the Georgian Iadgari and the Greek Tropologion. The oldest chant layer in Šaraknoc was made of these kzurds for Christmas, Lent, the Holy Week, Easter, etc. Also, the earliest Oktoechos in Armenian was found in Šaraknoc, see Аревшатян, А. Жанровая типология шараканов в системе восточнохристиянской гимнографии. In: Гимнология. Вып. 3, 2003, 12-20.

44 Winkler, G. Anhang zur Untersuchung: "Über die Entwliklungsgeschichte des Armenischen Symbolums" und seine Bedeutung für die Wirkungsgeschichte der Antiochenischen Synoden von 324/325 und 341-345. OCA, 271, 2004, 107-159. See also Winkler's article: Das theologische... C. Renoux points out such a connection especially for the repertory of Resurrection, see Renoux, C. Jerusalem...

45 Winkler, G. Die Licht-Erscheinung..., S. 196.

46 A. Arevshatian also considers the seventh and eighth centuries as a period of important changes in Armenian hymnography. Among these changes, she points 
out the introduction of both new genres and the system of the eight modes. The latter was linked to the name of Stepan Sunetcy who was also known as an author of numerous kanons. According to Arevshatian Stepan, writing his kanons, he should have learned a lot from Andrew of Crete. Arevshatian stresses also that in the works of the hymnographers of the cited time the best features of the Syrian and Byzantine hymnography were synthesized and developed on Armenian soil. The Saraknoc according to Aravshatian (she calls the book also "Hymnal") brings together all the books that were differentiated in the Byzantine Church and existed separately - the Tropologion, Heirmologion, Sticherarion, Oktoechos, Kontakarion, see Аревшатян, А. Жанровая типология..., pp. 16-19.

47 Jeffery, P. The Earliest Oktoechoi..., p. 151. According to F. Desby, there was a cycle of hymns in Syria in about the sixth century that were systematized in eight modal groups. The patriarch Severus had arranged these hymns in modal cycles in a way that they had to fit the eight Sundays during the seven weeks between Easter and Pentekost. The final compilation and adaptation for the worship in both the monasteries and churches was done by John of Damascus, see Desby, F. H. The Modes and Tuning in Neo-Byzantine Chant. Ann Arbor, MI, 1974, p. 41. The study has also shown that Syria was the main source for Eastern rituals in the shaping of their earliest anaphoras used in the Liturgy of St. Basil the Great, see Winkler, G. Licht-Erscheinung..., S. 206. According to the investigation of P. Tarchnišvili, from the very beginning the Georgian church belonged to the Syro-Palestinian region: its liturgical practice was linked with Jerusalem or with Antioch, see Tarchnišvili, P. M. Die Geschichte der kirchlichen georgischen Literatur. Studi e testi, 185, 1995, S. 440.

48 Wright, W. Catalogue of Syriac Manuscripts in the British Museum Acquired since the Year 1838. Vol. 1. London, 1870.

49 A. Baumstark believes that manito was a translation from Greek and meant antiphon in the sense of a hymnic, non-biblical response corresponding to the Latin responsorium, crf. Baumstark, A. Das Festbrevier und Kirchenjahr der syrischen Jakobiten. In: Studien zur Geschichte und Kultur des Altertums. B. 3, 3-5. Paderborn, 1910, S. 47. About this genre see also: Cody, A. The Early History of the Oktoechos in Syria. In: East of Byzantium: Syria and Armenia in the Formative Period. Ed. by N. Garsoian, T. Mathews, and R. Thomson. Washington, DC, 1982, 89-111; Taft, R. The Great Entrance. OCA, 200, 1975, p. 84 .

50 The latter opinion is defended by: Метревели, Е. Op. cit.; Wade, A. Op. cit.; Jeffery, P. The Lost Chant Tradition...; idem. The Sunday Office..., p. 53; idem. The Earliest Oktoechoi..., p. 197; Момина, М. О произхождении...

51 Куюмджиева, С. Ранните осмогласници... About the Sinai manuscripts see there pp. 13-17.

52 Crf. Никифорова, А. Ю. Рождение Минеи: греческие Минеи IX-XII вв. Вестник ПСТГУ, ІІІ: Филология, 2010. Вып. 4 (22), 103-122; Никифорова, А. Ю. Из истории Минеи в Византии. Гимнографические памятники VIII-XII вв. Из собрания монастыря святой Екатерины на Синае. Москва, 2012; Кривко, Р. Н. Синайско-славянские гимнографические параллели. Вестник ПСТГУ “Филология”. Вып. 1 (11). Москва, 2008, 56-102; also: Krivko, R. A Typology of Byzantine Office Menaia of the 9th-14th Century. Scrinium. Journal of Patrology, Critical Hagiography and Ecclesiastical History. Vol. 7-8: Ars Christiana. In Memoriam Michail F. Murianov (21.XI.1928-6.VI.1995). Part 2. Ed. by R. Krivko, B. Lourie, A. Orlov. Piscateway, NJ, 2011-2012, 3-68. 


\section{References}

Aland, K. Kurzgefasste Liste der griechischen Handschriften des Neuen Testaments. Band 1. Berlin, 1963. 2-te, neubearbeitete und ergänzte Auflage. Berlinund NY, 1994.

Alexakis, A. Was There Life Beyond the Life Beyond? Byzantine Ideas on Reincarnation and Final Restoration. DOP, 55, 2001, 155-179.

Alexandru, M. Zu dem Neumenkomplex kylisma, antikenokylisma, lygisma in der byzantinischer Musik. In: Palaebyzantine Notations, III. Ed. by G. Wolfram . Leuven, Paris, and Dudley, MA, 2004, 243-297.

Allen, P. Severus of Antioch and the Homily: The End or the Beginning? In: The Sixth Century. End or Beginning? Ed. by P. Allen and E. Jeffreys . Brisbane, 1996, 163-175.

Allison, R. W. The World Wide Web Archive of Watermarks and Papers in Greek Manuscripts. In: Byzantium. Identity, Image, Influence. XIX International Congress of Byzantine Studies: Major Papers. Ed. by K. Fledelius . Copenhagen, 1996, 465-476.

Arranz, M. Le Typicon du monastere du Saint-Sauveur a Messine. OCA, 185, 1969.

Artamonova, Y. On the Archaic Form of Znamennaja Notation (Neumes in the so-called lliya's Book). Българско музикознание, 3-4, 2012, 23-34.

Assemani, G. S. Bibliotheca orientalis Clementino-Vaticana. Rome, 1719.

Atiya, A. S. The Arabic Manuscripts of Mount Sinai. Baltimore, 1955.

Atkinson, C. M. The Critucal Nexus. Tone-System, Mode, and Notation in Early Medieval Music. AMS Studies in Music, Oxford University Press, 2009.

Bailey, T. The Development and Chronology of the Ambrosian Sanctorale. The Evidence of the Antiphon Texts. In: The Divine Office in the Latin Middle Ages. Ed. by M. Fassler and R. A. Baltzer . Oxford and NY, 2000, 257-277.

Baldovin, J. F. The Urban Character of Christian Worship. OCA, 228. Roma, 1987.

Baldovin, J. F. Liturgy in Ancient Jerusalem. Nothingham, 1989.

Baldovin, J. F. A Lenten Sunday Lectionary in Fourth Century Jerusalem. In: Time and

Community. In Honor of T. Talley. Ed. by J. N. Alexander. Washington, DC, 1990, 115-122.

Baldovin, J. F. Worship. City, Church, and Renewal. Washington, DC, 1991.

Baumstark, A. Das Festbrevier und Kirchenjahr der syrischen Jakobiten. In: Studien zur

Geschichte und Kultur des Altertums, B. 3, 3-5. Padernborn, 1910.

Baumstark, A. Ein frühchristliches Theotokion in mehrsprachiger Überlieferung und verwandte

Texte des ambrosianischen Ritus. Oriens Christianus. B. 9, 1920, 36-72.

Baumstark, A. Das Typikon der Patmos-Handschrift 266 und die altkonstantino- politanische Gottesdienstordnung. JL, VI, 1923, 98-111.

Baumstark, A. Denkmäler der Entstehungsgeschichte des byzantinischen Ritus. OC, 3e Série, II, 1927, 1-32.

Beneshevitch, V. Catalogue codicum mss graecorum, qui in monasterio Sanctae Catherinae in Monte Sina asservantur. I. Mss described by Ouspenski. III.1: Codices Nr. 1224-2150 signati. Petrograd, 1911, 1914.

Bertoniere, G. The Historical Development of the Easter Vigil and Related Services in the Greek Church. OCA, 193, 1972.

Bertoniere, G. The Sundays of Lent in the Triodion: The Sundays without Commemoration. OCA, 253, 1997.

Bradshaw, P. V. The Search for the Origins of Christian Worship, 2nd ed. New York, 2002.

Brock, S. P. From Ephrem to Romanus. SP, XX, 1989, 139-151.

Brock, S. Studies in Syriac Christianity. Variorum, 1992.

Brock, S. Syriac into Greek at Mar Saba: The Translation of St. Isaac the Syrian. In: The Sabaite Heritage in the Orthodox Church from the Fifth Century to the Present. Ed. by J. Patrich . Leuven, 2001, 201-209.

Brooks, E. W. The Hymns of Severus and Others in the Syriac Version of Paul of Edessa as Revised by James of Edessa. PO, VI, fasc. 1. Paris, 1911.

Brubaker, L. and J. Haldon . Byzantium in the Iconoclast Era (ca. 680-850): The Sources. Ashgate, 2001.

Brubaker, L. and M. Cunningham . Byzantine Veneration of the Theotokos: Icons, Relics, and Eight-Century Homilies. In: From Rome to Constantinople. Studies in Honor of Averil Cameron. Leuven, Paris and Dudley, MA, 2007, 235-251. 
Burkitt, F. C. The Early Syriac Lectionary System. Proceedings of the British Academy, vol. XI. Oxford, 1923 (2nd ed.: Piscataway, NJ, 2007).

Burkitt, F. C. The Jacobite Service for Holy Saturday. JTS, 24, 1923, 424-427.

Burkitt, F. C. The Old Lectionary of Jerusalem. JTS, 24, 1923, 415-424.

Canart, P. Codices Vaticani graeci. Codices 1745-1962. Part 1, Vaticana, 1970.

Carr, A. W. Illuminated Musical Manuscripts in Byzantium: A Note on the Late Twelfth Century. Gesta, 28, 1, 1989, 41-52.

Charlesworth, J. H. The New Discoveries in St. Catherine's Monastery: A Preliminary Report on the Manuscripts. Winona, 1981.

Clark, K. Checklist of Manuscripts in the St. Catherine's Monastery Mount Sinai. Washington, DC, 1952.

Clark, K. W. Checklist of Manuscripts in the Libraries of the Greek and Armenian Patriarchates in Jerusalem. Washington, DC, 1953.

Cody, A. The Early History of the Oktoechos in Syria. In: East of Byzantium: Syria and Armenia in the Formative Period. Ed. by N. Garsoian , T. Mathews, and R. Thomson . Washington, DC, 1982, 89-113.

Conybeare, F. C. Rituale Armenorum. Hildesheim, Zürich, and New York, 2004.

Crocker, R. and D. Hiley, eds. New Oxford History of Music, vol. 2: The Early Middle Ages to 1300. Oxford and NY, 1990.

Croke, B. The Early Byzantine Earthquakes and Their Liturgical Commemoration . Byzantion, LI, 1981, Fasc. 1, 122-147.

Cuming, G. J. The Liturgy of Antioch in the Time of Severus (513-518). In: Time and

Community..., Ed. by J. N. Alexander , 1990, 83-103.

Desby, F. H. The Modes and Tuning in Neo-Byzantine Chant. Ann Arbor and MI, 1974.

Devreese, R. Codices Vaticani graeci. Rome, T. II., 1937; T. III, 1950.

Devreese, R. Codices Vaticani graeci: Codices 604-866. T. 3. Vaticana, 1950.

Dyer, J. Liturgy and Liturgical Books . The New Grove Dictionary of Music and Musicians, 2nd ed. Ed. by S. Sadie, vol. 15, 1-10.

Džurova, A. , K. Stančev , V. Atsalos, and V. Katsaros . "Checklist" de la collection de manuscrits grecs conservee au centre de recherches slavo-byzantines "Ivan Dujčev" aupres de l'Universite "St. Clement d'Ohrid" de Sofia. Thessalonique, 1994.

Engberg, S. Greek Ekphonetic Notation: The Classical and the Pre-Classical Systems. In: Palaeobyzantine Notations, I. Ed. by J. Raasted and C. Troelsgård . Hernen, 1995, 33-55.

Falconer, K. The Modes before the Modes: Antiphon and Diferentia in Western Chant. In: The Study of Medieval Chant..., Ed. by P. Jeffery , 2001, 131-145.

Farmer, D. H. , ed. Oxford Dictionary of Saints, 4th ed. Oxford, 1997.

Fassler, M. Sermons, Sacramentaries, and Early Sources for the Office in the Latin West. In: The Divine Office..., Ed. by M. Fassler and R. A. Baltzer , 2000, 25-87.

Fassler, M. The First Marian Feast in Constantinople and Jerusalem: Chant Texts, Readings, and Homiletic Literature. In: The Study of Medieval Chant..., Ed. by P. Jeffery , 2001, 25-89.

Fassler, M. and R. Baltzer, eds. Divine Office in the Latin Middle Ages. Methodology and Source Studies, Regional Develppments, Hagiography. Written in Honor of Prof. Ruth Steiner. Oxford and NY, 2000.

Floros, C. Das mittelbyzantinische Kontakionrepertoire. Untersuchungen und kritische Edition. 3 Bde, Hamburg, 1961.

Floros, C . Gesang zum Lobpreis Gottes. Die Musik des Ostkirche. In: Das Buch der heiligen Gesänge der Ostkirche. Hamburg, 1962, 144-175.

Floros, C. Universale Neumenkunde, 3 Bde. Kassel, 1970.

Floros, C. Einführung in die Neumenkunde. Heinrichshofen, 1980.

Floros, C. Byzantinische Musiktheorie. In: Geschichte der Musiktheorie, B. 2. Herausg. von T. Ertelt , H. von Loesch und F. Zaminer . Darmstadt, 2006, 259-318.

Floros, C. The Origins of Russian Music. Introduction to the Kondakarion Notation. Frankfurt am Main, 2009.

Follieri, H. Initia Hymnorumecclesia Graecae. Studi e testi, 214, Vol. 4, 1963.

Follieri, E. and I. Dujćev . Un'akolutia inedita per i martiri du Bulgaria dell'anno 813. Byzantion, 33, 1964, 71-107. 
Follieri, E. and O. Strunk, eds. Triodium Athoum. Cod. Monasteri Vatopedi 1488. MMB, IX, Copenhagen, 1975.

Frøyshov, S. S. R. The Early Development of the Liturgical Eight-Mode System in Jerusalem. St. Vladimir's Theological Quarterly, 51, 2-3, 2007, 139-178.

Frøyshov, S. S. Greek Hymnody. In: Canterbury Dictionary of Hymnology. Ed. by I. R. Watson and E. Hornby . Norwich, 2013, 1-63.

Gagoshidze, G. Georgian Churches Dedicated to St. Sabas the Purified. OLA, 363-384.

Galadza, D. Two Greek Ninth-Century Sources of Jerusalem Lectionary: Sinai Gr. 212 and

Sinai Gr. NE MГ11. BBGG, 35, vol. 11, 2014, 79-113.

Gardhausen, V. E. Catalogus codicum graecorum sinaiticorum. Oxford, 1886.

Gartte, G. Aventures et mesaventures d'un manuscript Georgian (le cod. Garrett 24 Princeton). Bedi Cartlisa, 23-24, 1967, 37-52.

Gehin, P. and S. Frøyshov . Nouvelles decouvertes sinaitiques: a propos de la parution de l'inventaire des manuscrits Grecs. Revised English Bible, T. 58. Paris, 2000, 167-184.

Getov, D. Incipitarium for the Apparently Unedited Liturgical Kanons as Contained in the Greek Manuscripts Kept in Bulgarian Libraries. BBGG, III, vol. 1, 2004, 93-114.

Getov, D. A Catalogue of Greek Liturgical Manuscripts in the "Ivan Dujčev" Centre for SlavoByzantine Studies. OCA, 279. Roma, 2007.

Getov, D. and M. Yovcheva. The Unedited Oktoechos Canons for Prophets and Martyrs in the Byzantine and Slavic Tradition. Byzantinoslavica, LXVI, 2008, 1-2, 139-166.

Giannelli, C. Codices Vaticani graeci. Codices 1485-1683. Rome, 1950.

Gouma-Peterson, T. Originality in Byzantine Religious Paintings (Mosaics and Frescos). In: Originality in Byzantine Literature, Art, and Music. Ed. by A. R. Littlewood . Oxford, 1995, 125-145.

Grier, J. The Divine Office at Saint-Martial in the Early Eleventh Century. Paris, BNF lat. 1085. In: The Divine Office of the Middle Ages. Ed. by M. E. Fassler and R. A. Baltzer . New York, 2000, 193-196.

Guergova, E . Old Slavic Menaia: Structure and Content. In: Monastic Traditions. Selected Proceedings of the Fourth International Hilandar Conference. Ed. by C. Gribble and P. Matejic . Bloomington, IN, 2003, 143-153.

Guide to Microfilms of Vatican Library Manuscript Codices Available for Study in the Vatican Film Library at St. Louis University. Compiled by B. J. Chanell, L. J. Daly, and T. G. Tolles, St. Louis, 1993. Under the direction of C. J. Ermatinger.

Haelst, J. van. Cinq textes provenant de Khirbet Mird. Ancient Society, 22, 1991, 297-317. Hannick, C. Das "Slovo na prenesenie mostem Sv. Klimenta" als liturgiegeschichtliche Quelle. OCA, 231, 1988, 27-236.

Hannick, C. The Theotokos in Byzantine Hymnography: Typology and Allegory. In: Images of the Mother of God. Perception of the Theotokos in Byzantium. Ed. by M. Vassilaki . Ashgate, 2004, 69-76.

Harlfinger, D. , D. Reinsch, and A. M. Sonderkamp . Specimina Sinaitica. Die datierten griechischen Handschriften des Katharinen-Klosters auf dem Berg Sinai 9. bis 12. Jahrhundert. Berlin, 1983.

Harris, S. Psalmodic Traditions and the Christmas and Epiphany Troparia as Preserved in 13thCentury Psaltika and Asmatika. In: Cantus Planus. Budapest, 1990, 205-211.

Harris, S. Double Pauses in Byzantine Psaltika and Asmatika. In: Cantus Planus. Budapest, 1995, 403-409.

Hilley, D. Plainchant Transfigured: Innovation and Reformation through the Ages. In: Antiquity and the Middle Ages. From Ancient Greece to the 15th Century. Ed. by J. McKinnon . New Jersey, 1991, 120-142.

Huglo, M. Les Tonaires: Inventaire, Analyse, Comparaison. Paris, 1971.

Huglo, M. The Cluniac Processional Solesmes. Bibliotheque de l'Abbaye, Reserve 28. In: The Divine Office in the Latin Middle Ages., Ed. by M. E. Fassler and R. A. Baltzer . New York, 2000, 205-213.

Husmann, H. Himnus und Troparion. In: Jahrbuch des Staatlichen Instituts der Internationalen Musikforschung Preussischer Kulturbesitz. Berlin, 1971, 46-57.

Husmann, H. Die syrischen Auferstehungskanones und ihre griechischen Vorlage. OCP, 38, 1972, 209-242. 
Husmann, H. Die syrischen Handschriften des Sinai-Klosters, Herkunft und Schreiber. OS, 24, 1975, 281-308.

Husmann, H. Ein Syro-Melkitisches Tropologion mit altbyzantinischen Notation Sinai Syr. 261. Göttinger Orientforschungen, 9. Wiesbaden, 1975.

Husmann, H. Eine alte orientalische christliche Liturgie: altsyrisch-melkitisch. OCP, 42, 1976, 156-196.

Husmann, H. Syrischer und byzantinischer Oktoechos. Kanones und Qanune. DOP, 44, 1978, 65-73.

Husmann, H. and P. Jeffery . Syrian Church Music. In: The New Grove..., 2nd ed., vol. 24. Ed. by S. Sadie . 2001, 857-867.

Inventory of Microfilms and Photographs in the Collection of Monumenta Musicae Byzantinae (Institute for Greek and Latin, University of Copenhagen). Compiled by C. Troelsgård .

Copenhagen, 1992.

Jacobsson, R. The Antiphoner of Compiegne. Paris, BNF lat. 17, 436. In: The Divine Office in the Latin Middle Ages..., Ed. by M. Fassler and R. A. Baltzer , 2000, 147-178.

Jeannin, J. and J. Puyade . L'Octoechos syrien. OC, 3, 1913, 82-104, 277-298.

Jeffery, P. Jerusalem and Rome (and Constantinople): The Musical Heritage of Two Great Cities in the Formation of the Medieval Chant Traditions. In: Cantus Planus. Budapest, 1980, 163-175.

Jeffery, P. The Sunday Office of Seventh-Century Jerusalem in the Georgian Chant Books (ladgari): A Preliminary Report. SL, 21, 1991, 52-75.

Jeffery, P. The Lost Chant Tradition of Early Christian Jerusalem: Some Possible Melodic Survivals in the Byzantine and Latin Chant Repertories. EMH, 11, 1992, 151-190.

Jeffery, P. The Earliest Christian Chant Repertories Recovered: The Georgian Witnesses to Jerusalem Chant. JAMS, 47, 1994, 1-39.

Jeffery, P. Eastern and Western Elements in the Irish Monastic Prayer of the Hours. In: The Divine Office..., Ed. by M. Fassler and R. A. Baltzer , 2000, 99-147.

Jeffery, P. Oktoechos . The New Grove Dictionary of Music..., Ed. by S. Sadie, 2nd ed., vol. 18. 2001, 370-371.

Jeffery, P. The Earliest Oktoechoi: The Role of Jerusalem and Palestine in the Beginning of Modal Ordering. In: The Study of Medieval Chant.,: Ed. by P. Jeffery , 2001, 147-211.

Jeffery, P . A Window of the Formation of the Medieval Chant Repertories: The Greek

Palimpsest Fragments in Princeton University MS Garrett 24. In: Cantus Planus, vol. 2.

Budapest, 2003, 1-23.

Jeffery, P. Monastic Reading and the Emerging Roman Chant Repertory. In: Western

Plainchant in the First Millennium. Studies in the Medieval Liturgy and Its Music. Ed. by S. Gallagher, J. Haar, and T. Striplin . Ashgate, 2003, 5-103.

Jordan, R. H. The Monastery of the Theotokos Evergetis, Its Children and Grandchildren. In: The Theotokos Evergetis...., Ed. by M. Mullett and A. Kirby , 1994, 215-245.

Jordan, R. H. John of Phoberou: A Voice Crying in the Wilderness. In: Strangers to Themselves: The Byzantine Outsider. Ed. by D. C. Smythe . Ashgate-Variorum, 2000, 61-75. Jung, A. The Kathismata in the Sofia Manuscript Kliment Ohridski Cod. Gr. 814. Cahiers de I'Institut du moyen-age grec et latin, 61. Copenhagen, 1991, 49-77.

Jungmann, J. The Early Liturgy. Notre Dame, 1959.

Kamil, M. Catalogue of All Manuscripts in the Monastery of St. Catherine on Mount Sinai. Wiesbaden, 1970.

Kazhdan, A. , ed. Oxford Dictionary of Byzantium, 3 vols. Oxford, NY, 1991.

Klentos, J. The Synaxarion of Evergetis: Algebra, Geology and Byzantine Monasticism. In: Work and Worship at the Theotokos Evergetis 1050-1200. Ed. by M. Mullet and A. Kirby . Belfast, 1997, 329-355.

Krausmüller, D. The Monastic Communities of Stoudios and St. Mamas in the Second Half of the Tenth Century. In: The Theotokos Evergetis and Eleventh-Century Monasticism...., Ed. by M. Mullett and A. Kirby , 1994, 67-85.

Krivko, R. A. Typology of Byzantine Office Menaia of the 9th-14th Century. Scrinium. Journal of Patrology, Critica Hagiography and Ecclesiastical History, vol. 7-8, 2011-2012, 3-68.

Kujumdzieva, S. Viewing the Earliest Old Slavic Corpus Cantilenarum. Palaeobulgarica, 2, 2002, 83-101. 
Kujumdzieva, S. In Searching for the Earliest Oktoechoi: The Book of the Tropologion. In: Musica Antiqua Europae Orientalis, XIV. Bydgoszcz, 2006, 55-65.

Lake, K. and S. Lake, eds. Dated Greek Minuscule Manuscripts to the Year 1200, 10 vols. Boston, MA, 1934-1945 (Vol. 8: Manuscripts in Rome Part II. Boston, MA, 1937).

Leeb, H. Die Gesänge im Gemeindegottesdienst von Jerusalem (vom 5. bis 8. Jahrhundert). In: Wiener Beiträge zur Theologie, B. XXVIII. Wien, 1970.

Lingas, A. Sunday Matins in the Byzantine Cathedral Rite: Music and Liturgy. Ph.D. University of British Columbia, 1996.

Louth, A. John of Damascus and the Making of the Byzantine Theological Synthesis. OLA: The Sabaitic Heritage in the Orthodox Church from the Fifth Century to the Present, 98, 2001, 301-304.

Mango, C. Oxford History of Byzantium. Oxford, 2002.

Mary, M. and K. Ware. The Festal Menaion. London, 1969.

Mary, M. and C. Ware. The Lenten Triodion. London and Boston, 1978.

Mateos, J. Le Typicon de la Grande Eglise. Ms. Saint-Croix n. 40, Xe siecle. OCA, 165, 1962; 166, 1963.

Mateos, J. The Morning and Evening Office. Worship, 42, 10, 1968, 31-47.

McKinnon, J. , ed. Music in Early Christian Literature. Cambridge, 1987.

McKinnon, J. Christian Church, Music of the Early. The New Grove..., 2nd ed., vol. 5. 2001, 795-807.

McKinnon, J. The Emergence of Gregorian Chant in the Carolingian Era. In: Antiquity and the Middle Ages. From Ancient Greece to the 15th Century. Ed. by J. McKinnon . New Jersey, 1991, 88-119.

McKitterick, R. The Book of Memory. A Study of Memory in Medieval Culture. Cambridge, 1990. McKitterick, R. History and Memory in the Carolingian World. Cambridge, 2004.

Momina, M. A. and N. Trunte, eds. Triodion und Pentekostarion nach slavischen Handschriften des 11.-14. Jahrhunderts. Paderborn, München, Wien, and Zürich, 2004.

Moolan, J. The Period of Annunciation-Nativity in the East Syrian Calendar. Kottayam, 1985.

Moran, N. K. Ordinary Chants of the Byzantine Mass. In: Hamburger Beiträge zur

Musikwissenschaft, 12. Hamburg, 1975, 2 vols. Vol. 1.

Moutsopoulos, E. A. Modal "Ethos" in Byzantine Music: Ethical Tradition and Aesthetical

Problems. In: XVI. Internationaler Byzantinistenkongress: Akten II/7, Jahrbuch für

Österreichischen Byzantinistik, 32/7. Vienna, 1982, 3-6.

Mullet, M. Introduction: The Monastery of the Theotokos Evergetis. In: The Theotokos Evergetis and Eleventh-Century Monasticism. Ed. by M. Mullett and A. Kirby . Holywood, 1994, 1-16.

Murray, R. The Characteristics of the Earliest Syriac Christianity. In: East of Byzantium: Syria and Armenia in the Formative Period. Ed. by N. Garsoian , T. Mathews, and R. Thomson . Washington, DC, 1982, 3-17.

Nardini, L. Alience in Disguise: Byzantine and Gallican Chants in the Latin Liturgy. PMM, 16, 2007, 145-172.

Nikiforova, A. The Tropologion Sin. Gr. NE/MГ 56-5 of the Ninth Century: A New Source of Byzantine Hymnography. In: Scripta \& E-Sripta, 12, 2013, 157-185.

Nikolopulos, P. G. et al. The New Finds of Sinai. Athens, 1999.

Nowacki, E. The Distributional Evidence for Orality. In: Studies in Medieval Chant and Liturgy in Honour of David Hiley. Ed. by T. Bailey and L. Dobszay . Ottawa, 2007, 369-383.

Olivier, J.-M. Repertoire des bibliotheques et des catalogues de manuscrits grecs de Marcel Richard, 3rd ed. In: Corpus Christianorum. Turnhout, 1995.

Palikarova-Verdeil, R. La musique Byzantine chez les Bulgares et les Russes (du IXe au XIVe siecle). MMB, Subsidia, III. Copenhagen, 1953.

Panagiotides, P. The Musical Use of Psalter in the 14th and 15th Centuries. In: Byzantine Chant. Tradition and Reform. Ed. by C. Troelsgård . Monographs of the Danish Institute of Athens, vol. 2. Athens, 159-171.

Papathanasiou, J. and N. Boukas . Early Diastematic Notation in Greek Christian Hymnographic Texts of Coptic Origin. A Reconsideration of the Source Material. In: Palaeobyzantine

Notations, III. Ed. by G. Wolfram . Louven, Paris, and Dudley, MA, 2004, 1-25.

Parenti, S. and E. Velkovska. Two Leaves of a Calendar Written in "Mixed" Uncial of the Ninth Century. BBGG, 7, 2010, 297-305. 
Parry, K. , D. Brady , S. Grlfflth , and J. Healy , eds. Blackwell Dictionary of Eastern Christianity. Oxford, 1999.

Patrich, J. Sabas, Leader of Palestinian Monasticism. Washington, DC, 1995.

Patterson-Ševčenko, N. Canon and Calendar: The Role of a Ninth Century Hymnographer in Shaping the Celebration of the Saints. In: Byzantium in the Ninth Century: Dead or Alive? Variorum. Ed. by L. Brubaker . 1996, 101-114.

Patterson-Ševčenko, N. The Evergetis Synaxarion and the Celebration of a Saint in 12thCentury Art and Liturgy. In: Work and Worship...., Ed. by M. Mullett and A. Kirby , 1997, 386-399.

Payne, R. M. Christian Worship in Jerusalem in the Fourth and Fifth Centuries: The Development of the Lectionary, Calendar, and Liturgy. Ph.D. Ann Arbor and London, 1982. Perria, L. and J. Raasted, eds. Sticherarium Ambrosianum. MMB, XI, Pars Suppletoria. Copenhagen, 1992.

Petersen, W. L. The Dependence of Romanos the Melodist Upon the Syriac Ephrem: Its Importance for the Origin of the Kontakion. VC, 39, 1985, 171-187.

Petrović, D. Osmoglasnik u musičkoj tradicii južnih slovena. Beograd, 1982.

Petrović, D. The Selection of Tones in the Services for the Twelve Great Feasts. In:

Palaeobyzantine Notations, III. Ed. by G. Wolfram . Leuven, Paris, and Dudley, MA, 2004, 211-226.

Pfaff, R. W. Telling Liturgical Times in the Middle Ages. In: Procession, Performance, Liturgy and Ritual. Essays in Honor of Bryan R. Gillingham. Ed. by N. van Deuse . Ottawa, 2007, 43-64.

Pitra, C. Codices manuscripti graeci. Reginae svecorum et. PiiPp.IIBibliothecae Vaticanae, descripti praeside I. B. Cardinali Pitra (recensuit et digessit H. Stevenson Sr.). Romae, 1888. Popović, S. Are Typika Sources for Architecture? The Case of the Monasteries of the Theotokos Evergetis, Chilandari, and Studenica. In: Work and Worship...., Ed. by M. Mullett and A. Kirby , 1997, 266-284.

Raasted, J. A Primitive Palaeobyzantine Musical Notation. Classica and Medieavalia, 23, 1962, 302-310.

Raasted, J. , ed. Hirmologium Sabbaiticum Codex Monasterii S. Sabbae 83. MMB. Serie Principale, 8/1. Copenhagen, 1968.

Raasted, J. The Hagiopolites: A Byzantine Treatise on Musical Theory. Cahiers de I'Institut du Moyen-Age Grec et Latin, 45, 1983.

Raasted, J. The Princeton Heirmologion Palimpsest. Cahiers de l'Institut du Moyen-Age Grec et Latin, 62, 1992, 219-232.

Raasted, J. The Hagiopolitis in 15th Century Italy. A Note on Manuscript Terminology. BBGG, XLVI, 1992/1993.

Raasted, J. Kontakion Melodies in Oral and Written Tradition. In: The Study of Medieval Chant...., Ed. by P. Jeffery , 2001, 273-281.

Rapp, C. Byzantine Hagiographers as Antiquarians, Seventh to Tenth Centuries. In: Bosphoros. Essays in Honour of Cyril Mango. Ed. by S. Efthymiadis , C. Rapp , and D. Tsougarakis . Amsterdam, 1995, 33-44.

Renoux, C. Le ladgari géorgien et le saraknoc' arménien. Revue des Études arméniennes, 24, 1993, 89-112.

Renoux, C. Jerusalem dans le Caucase: Anton Baumstark verifie. OCA, 265, 2001, 305-321.

Renoux, Ch . L'Hymnaire de Saint-Sabas (Ve-VIIle siecle): le manuscrit Georgien H 2123. I. Du samedi de Lazare a la Pentecote. PO, 50, fasc. 3, 2008.

Richter, L. Zur Lehre von den byzantionischen Tonarten: Kenntnisse, Erkenntnisse und Probleme. Jahrbuch des Staatlichen Instituts für Musikforschung Preussischer Kulturbesitz, Teil I, 1996, 211-260, Teil II, 1997, 325-390.

Roberts, C. H. Catalogue of the Greek and Latin Papyri in the John Rylands Library at Manchester, IV. Manchester, 1952.

Sadie, S. , ed. New Grove of Music and Musicians, 2nd ed. New York, 2001.

Schidlovsky, N. The Notated Lenten Prosomoia in the Byzantine and Slavic Traditions. Ph.D., Princeton University, 1983.

Schidlovsky, N. A New Folio for Mt. Athos MS Chilandari 307 and Some Observations on the Contents of the Slavic Lenten Sticherarion and Pentekostarion. In: The Study of Medieval Chant. Ed. by P. Jeffery , 2001,... 105-123. 
Schiro, I. Analecta hymnica graeca e codicibus eruta Italiae inferioris. 13 vols. Rome, 1966-1983.

Schneider, H.-M. Lobpreis im rechten Glauben. Die Theologie der Hymnen an den Festen der Menschwerdung der alten Jerusalemer Liturgie im Georgischen Udzvelesi Iadgari. In: Studien zur alten Kirchengeschichte, 23. Borengasser-Bonn, 2004.

Schulz, H. J. The Byzantine Liturgy. New York, 1986.

Senn, F. C. Christian Liturgy. Minneapolis, 1997.

Shkolnik, I. On the Problem of the Evolution of the Byzantine Stichera in the Second Half of the V-VIIth Centuries: From the "Echos Melodies" to the Idiomela. In: Cantus Planus, vol. 2.

Budapest, 1993, 409-425.

Shkolnik, I. Byzantine Prosomoion Singing: A General Survey of the Repertoire of the Notated Stichera Models (Automela). In: Cantus Planus, 1998, 521-536.

Steiner, R. On the Verses of the Offertory Elegerunt . In: The Study of Medieval Chant... Ed. by P. Jeffery , 2001, 283-301.

Strunk, O. Specimina Notationum Antiquiorum. MMB. VII. Copenhagen, 1965.

Strunk, O. Tropus and Troparion. In: Speculum Musicae Artis, Festgabe für Heinrich Husmann. Ed. by H. Becker and R. Gerlach . Münich, 1970.

Strunk, O. Essays on Music in the Byzantine World. Ed. by K. Levy . New York, 1977.

Taft, R. The Great Entrance. OCA, 200, 1975.

Taft, R. The Liturgy of the Great Church: An Initial Synthesis of Structure and Interpretation on the Eve of Iconoclasm. DOP, Part 1, 34-35, 1980-1981, 45-77; Part 2, 36, 1980, 89-124.

Taft, R. Mount Athos: A Late Chapter in the History of Byzantine Rite. DOP, 42, 1982, 179-194.

Taft, R. The Liturgy of the Hours in East and West. Collegeville, 1986.

Taft, R. The Byzantine Rite. Collegeville, 1992.

Taft, R. The Synaxarion of Evergetis in the History of Byzantine Liturgy. In: The Theotokos

Evergetis.... Ed. by M. Mullett and A. Kirby , 1994, 274-293.

Taft, R. The Liturgy in Byzantium and Beyond. Variorum, 1995.

Taft, R. The bhmatikion in the 6/7th c. Narration of the Abots John and Sophronius (BHGNA 1438w). An Exercise in Comparative Liturgy. - OCA, 260, 2000, 675-693.

Taft, R. The Precommunion Rites. OCA, 261, 2000.

Taft, R. Anton Baumstark's Comparative Liturgy Revisited. - OCA, 265, 2001. Comparative Liturgy Fifty Years after Anton Baumstark (1872-1948), 191-232.

Taft, R. Divine Liturgies-Human Problems in Byzantium, Armenia, Syria, and Palestine. Variorum. Ashgate, 2001.

Taft, R. Christian Liturgical Psalmody: Origins, Development, Decomposition, Collapse. In: Psalms in Community. Jewish and Christian Textual, Liturgical, and Artistic Traditions. Ed. by $\mathrm{H}$. W. Attridge and M. Fassler . Atlanta, 2003, 7-33.

Talley, T. J. The Origins of the Liturgical Year. New York, 1986; 2nd ed. Collegeville, MN, 1991. Talley, T. J. Afterthoughts of the Origin of the Liturgical Year. In: Western Plainchant in the First Millennium. Studies in Medieval Liturgy and Its Music. Ed. by S. Gallagher, J. Haar, J. Nadar , and T. Striplin . Ashgate, 2003, 1-10.

Tarchnishvili, P. Die Geschichte der kirchlichen georgischen Literatur. Studi e Testi, 185, 1995. Tarnanidis, J. C. The Slavonic Manuscripts Discovered in 1975 at St. Catherine's Monastery on Mount Sinai. Thessaloniki, 1988.

Thibaut, J.-B. Monuments de la Notation Ekphonetique et Hagiopolite de'Eglise Grecque. Hildesheim, NY, 1976.

Thodberg, C. Der byzantinische Alleluiarionzyklus: Studien im kurzen Psaltikonstil. MMB, 8, Subsidia. Copenhagen, 1966.

Thomas, J. The Imprint of Sabaitic Monasticism on Byzantine Monastic Typika. OLA, 98. Leuven, 2001: The Sabaite Heritage in the Orthodox Church from the Fifth Century to the Present, 73-83.

Thomas, J. and A. C. Hero, eds. Byzantine Monastic Foundation Documents, 5 vols. Washington, DC, 2000.

Touliatos-Banker, D. Checklist of Byzantine Musical Manuscripts in the Vatican Library. Manuscripta, 31, 1, 1987, 22-28.

Treu, K. and J. Diethart . Griechische literarische Papyri christlichen Inhaltes. II (Textband und Tafelband). Vienna, 1993. 
Troelsgård, C. An Early Constantinopolitan Sticherarion MS Leukosia, Archbishopric of Cyprus, Musikos 39, and Its Notated Exaposteilaria Anastasima. Palaeobyzantine Notations, 2. Ed. by G. Wolfram . Hernen, 1999, 159-173.

Troelsgård, C. A New Source for the Early Oktoechos? Papyrus Vindobonensis G 19.934 and Its Musical Implications. In: Proceedings of the 1st InternationalConference of the American Society of Byzantine Music and Hymnography. 668-679. Published in Internet:

www.asbmh.pitt.edu/page9/page9.html.

Troelsgård, C. Songs for the Theotokos. Pieces of Papyrus and the Early Byzantine Theotokia. In: Cantus Planus. Budapest, 2013, 5-24.

Trunte, N. . Vor- und Frühgeschichte der slavischen Hymnography. In: Sacrale Grundlagen slavischer Literaturen. Herausg. von H. Rothe. Bd. 43. München, 2002, 27-76.

Velimirović, M. Byzantine Elements in Early Slavic Chant. MMB, IV, Subsidia, 2 vols.

Copenhagen, 1960.

Velimirovic, M. Christian Chant in Syria, Armenia, Egypt, and Ethiopia. New Oxford History of Music, vol. 2: The Early Middle Ages to 1300. Ed. by R. Crocker and D. Hiley . Oxford, NY, 1990, 3-66.

Velkovska, E. Funeral Rites according to the Byzantine Liturgical Sources. DOP, 55, 2001, 21-51.

Wade, A. The Oldest Jadgari. The Jerusalem Tropologion, V-VIII Century. OCP, 50, 1984, 451-456.

Walter, C. Art and Ritual of the Byzantine Church. London, 1982.

Ware, K. The Orthodox Church. London, 1963.

Wegman, H. A. J. Christian Worship in East and West. New York, 1985.

Wellesz, E. Das serbische Oktoechos und die Kirchentone. Musica Sacra, Heft 2. Regensburg, 1917, 17-19.

Wellesz, E. Die Struktur des serbischen Oktoechos. Zeitschrift für Musikwissenschaft, II. Leipzig, 1919-1920, 140-148.

Wellesz, E. The Music of the Byzantine Church. Köln, 1959.

Wellesz, E. A History of Byzantine Music and Hymnography. Oxford, 1961.

Werner, E. Die judische Wurzeln der christlichen Kirchenmusik. - In: Geschichte der katholischen Musik, B. 1. Kassel, 1972, S. 22-31.

Werner, E. The Sacred Bridge. Vol. 1, London and New York, 1959; vol. 2, New York, 1984. Wilkinson, J. Egeria's Travels to the Holy Land. Newly Translated with Supporting Documents and Notes. Jerusalem and Warminster, 1981.

Winkler, G. Die Licht-Erscheinung bei der Taufe Jesu und der Ursprung des Epiphaniefestes. Oriens Christianus, 78, 1994, 177-229.

Winkler, G. Der armenische Ritus: Bestandsaufnahme und neue Erkentnisse sowie eine kürzere Notizen zur Liturgie der Georgier. OCP, 251, 1996, 265-298.

Winkler. G. Studies in Early Christian Liturgy and Its Context. Variorum. Ashgate, 1997.

Winkler, G. Das theologische Formelgut über den Schöpfer, das omoou//sioj, die Inkarnation und Menschwordung in den georgischen Troparien des ladgari im Spiegel der christlichorientalischen Quellen. OC, 84, 2000, 117-178.

Winkler, G. Das Sanctus . Über den Ursprung und die Anfänge des Sanctus und sein Fortwirken. OCA, 267, 2002. Teil II: Das georgische Troparion bei den Gabenprozesion nach dem georgischen Lektionar und Jadgari (Troparien-Samlung).

Winkler, G. Anhang zur Untersuchung: "Über die Entwliklungsgeschichte des Armenischen Symbolums" und seine Bedeutung für die Wirkungsgeschichte der Antiochenischen Synoden von 324/325 und 341-345. OCA, 271, 2004, 107-159.

Wolfram, G. , ed. Sticherarium Antiquum Vindobonense. MMB, 10. Wien, 1987.

Wolfram, G. Severus of Antioch. The New Grove Dictionary of Music..., 2nd ed., vol. 23. 2001, 176-177.

Wolfram, G. Der Codex Ochrid 53. Ein Sticherarion aus dem Einflussbereich Konstantinopels. In: Eastern Christian Studies, III: Palaeobyzantine Notations. Ed. by G. Wolfram . Leuven, Paris, and Dudley, MA, 2004, 227-241.

Wright, W. Catalogue of Syriac Manuscripts in the British Museum Acquired since the Year 1838, vol. 1. London, 1870.

Yevics, P. E. Lazarus Saturday in the Byzantine Tradition. Ph.D., Drew University, Madison, New Jersey, 1977. 
Ангелов, Б . Старобългарски текстове. - Известия на Архивния институт при БАН, 1, 1957, 267-303.

Аревшатян, А . Жанровая типология шараканов в системе восточнохристиянской гимнографии. В: Гимнология, вып. 3. Москва, 2003, 12-20.

Бенешевич, В. Н. Описание греческих рукописей монастыря святой Екатерины на Синае. Санкт Петербург, 1911.

Библия. София, 1991.

Бруни, А.-М. Древнеславянский ирмологий и гимнографические традиции Святой земли: к вопросу о произхождении византийского прототипа. B: Jews and Slavs, vol. 20. Jerusalem and Sofia, 2008, 301-316.

Велковска, Е. Система на византийските и славянските богослужебни книги в периода на възникването им. В: Средновековна християнска Европа:Изток и Запад. София, 2002, 220-236.

Верещагин, Е. М. Ильина книга.Древнейший богослужебный сборник. Москва, 2006.

Верещагин, Е. М. Наименьшие поэтико-смысловые единицы в греко-славянской гимнографрии (на материале Ильинской книги). B: Liturgische Hymnen nach byzantinischen Ritus bei den Slaven in ältester Zeit. Beiträge einer internationalen Tagung. Herausg. von H. Rothe and D. Christians. Paderborn, 2007, 397-438.

Генов, Я. Антифонарът в Средновековието и съвременността: сравнително изследване.Цикълът Quadragesima. Дисертация. София, 2008.

Георгиева-Куюмджиева, С. Седмичните херувимски песни в репертоара от XIX в. БМ, 2, 1982, 56-72.

Георгиева, С. Интонационните фоормули (ихими) като елемент от осмогласната система. Списъци с ихими във византийски пападики-трактати. БМ, 3-4, 2007, 91-125.

Гюзелев, В. Студийският манастир и българите през средновековието. В: Зборник радова Византолошког института, XXXIX, 2001/2002, 53-67.

Димитрова, М. Прокимените във византийско-славянската певческа традиция на Балканите през XIV и XV в. Дисертация. Софрия, 1999.

Димитрова, М. Тита-нотацията във византийски и славянски ръкописи (XI-XIII век). БМ, 3-4, 2007, 31-45.

Димитрова, М. Богослужебната книга миней като музикален извор: гръцки и славянски нотирани минеи от XI-XIII в. В: Пети достоит. Сборник в памет на Стефан Кожухаров. Сосия, 2003, 601-620.

Дмитриевский, А. Описание литургических рукописей,хранящихся в библиотеках православного Востока. Т. І. Киев, 1895.

Добрев, И. Климентовото химнографрско творчество и Октоихът. В: 1080години от смъртта на св. Наум Охридски. Софияя, 1993, 107-123.

Иванов, И. Между ангелите и човеците. Сосия, 2006.

Иванов, Й. Български старини из Македония. София, 1931.

Иванова-Константинова, К. Два неизвестни азбучни акростиха с глаголическа подредба на буквите в среднобългарски празничен миней. В:Константин-КирилФилософр. Доклади от симпозиума, посветен на 1100 годишнината от смъртта му. София, 1971, 341-365. Йовчева, М. Композиция на неделните служби в Солунския октоих. Палеобулгарика, 4, 1997, 37-72.

Йовчева, М. Новооткрити химнографски произведения на Климент Охридски в октоиха. Палеобулгарика, 3, 1999, 3-25.

Йовчева, М. Солунският Октоих в контекста на южнославянските октоиси до XIV в.КМС, 16. София, 2004.

Йовчева, М. Древнеславянский Октоих: реконструкция его состава и структуры. B:Liturgische Hymnennach, 2007,... 50-73.

Йовчева, М. Службите за празника на св. Георги на 26 ноември в южнославянските минеи. В:Пение мало Георгию. Сборник в чест на 65-годишнината на проф. д.ф.н. Георги Попов. София, 2010, 101-116.

Каврус, Н. Ф. Студийский скрипторий в IX в. (по материалам рукописей Москвы и Ленинграда). Византийский временник, 44, 1983, 98-112.

KME. София, т. II, 1995, т. IV, 2003.

Карабинов, И. Постная триод. С.-Петербург, 1910. 
Кекелидзе, К. Литургические грузинские памятники в отечественных книгохранилищах и их научное значение. Тисрилис, 1908.

Кожухаров, С. Нотни начертания в Орбелския триод.БЕ, 4, 1974, 324-344.

Кожухаров, С. Палеографски проблеми на тита-нотацията в средновековните ръкописи от XII-XIII век.Славянска палеографрия и дипломатика. Т. 1, София, 1980, 228-247.

Крашенинникова, О. К истории фрормирования седмичных памятей октоиха.Богословские труды, 32. Москва, 1996, 260-267.

Крашенинникова, О. Ранневизантийские источники славянского Октоиха XIII-XIV вв. В:Гимнология, вып. 1. Москва, 2000, 114-123.

Крашенинникова, О. Древнеславянский Октоих св. Климента архиепископа Охридского. По древнерусским и южнославянским спискам XIII-XV веков. Москва, 2006.

Кривко, Р. Синайские унциальные гимнографические сборники и их значения для славянской традиции. B:Jews and Slavs, 20. Jerusalem and Sofia, 2008, 317-339.

Кривко, Р.Н.Синайско-славянские гимнографические параллели.Вестник ПСТгУ, Филология. Вып. 1 (11). Москва, 2008, 56-102.

Крысько, В. Б. Ильина книга. Рукопись РГДА, Тип. 131. Лингвистическое издание, подготовка греческого текста, коментарии, словоуказатели В. Б. Крысько. Москва, 2005. Крысько, В. Б. Еще раз об Имоволожи. Slavica Helsingiensia, 27. Helsinki, 2006, 222-233. Куюмджиева, С. Стихирарът на Йоан Кукузел. Формиране на нотирания възкресник. София, 2004.

Куюмджиева, С. Отново за ранните осмогласници: какво ни казват синайски гръцки ръкописи 1593 и 776?СЛ, 37-38, 2007, 26-48.

Куюмджиева, С. Проучвайки ранните осмогласници: нови данни. КМС, 17. София, 2008, 453-464.

Куюмджиева, С. Бележки и коментари за някои ранни химнографски ръкописи от Ватикана. В:Богослужебните книги -познати и непознати. София, 2008, 43-155.

Куюмджиева, С. Ранните осмогласници. Извори, богослужение и певчески репертоар. София, 2013.

Лозовая, И. Е. Древнерусский нотированный Параклитик конца XII - начала XIII века: предварительные заметки к изучению певческой книги. В:Герменевтика древнерусской литературы. Сб. 6. Ч. 2. Москва, 1993, 407-432.

Лозовая, И. Древнерусский нотированый Параклит в кругу Ирмологиев XII века-первой половине XV в.: мелодические варианты и версии в роспеве канонов. В:Гимнология. Вып. 1, кн. первая. Москва, 2000, 217-239.

Лозовая, И. О системе пения седмичных канонов Октоиха в ранней литургической традиции. В:Гимнология, вып. 4, Москва, 2003, 52-68.

Матеијћ, М. Егерија. Путованьа по светој земльи. Београд, 2002.

Метревели, Е. П. , Ц. А. Чанкиева, Л. М. Хевсуриани . Древнейший иадгари. Тбилиси, 1980.

Минія общая. Москва, 1960.

Момина, М. А. О произхождении греческой триоди.Палестинский сборник. Вып. 28. Москва, 1986, 112-121.

Момина, М. Постная и цветная триод. В:Методические рекомендации по описанию славяно-русских рукописей для Сводного каталога рукописей, хранящихся в СССР, т. 2, вып. 2. Москва, 1976, 389-418.

Никифророва, А. Ю. Проблема происхождения служебной минеи: структура, состав, месяцослов греческих миней IX-XII вв. из монастыря Святой Екатерины на Синае. Авторефрерат дисертации. Москва, 2005.

Никифорова, А. Ю. Рождение Минеи: греческие Минеи IX-XII вв.Вестник ПСТГУ, III: Филология, 2010, вып. 4 (22), 103-122.

Никифорова, А. Ю. “Сокрытое сокровище”. Значеие находок 1975 года на Синае для истории Минеи. В:Гимнология. Т. 6. Москва, 2011, 8-31.

Никифорова, А. Ю. Из истории Минеи в Византии. Гимнографические памятники VIII-XII вв. Из собрания монастыря Святой Екатерины на Синае. Москва, 2012.

Пентковский, А. М. Типикон патриархаАлексия Студита в Византии и на Руси. Москва, 2001.

Пентковский, А. , М. Йовчева . Праздничные и воскресные блаженны в византийском и славянском богослужении VIII-XIII Вв. Палеобулгарика, 3, 2001, 31-60. 
Петров, С. , Х. Кодов . Старобългарски музикални паметници. София, 1973.

Плетнева, Е.В.Певческие параллели в южнославянских и древнерусских октоихах Студийской редакции. В:Греко-русские певческие параллели. Ред. А. Н. Кручинина и Н. В. Рамазанова. Москва и Санкт Петербург, 2008, 87-99.

Попов, Г. Из текстологическата проблематика на славянския триод (Новооткрити творби на Константин Преславски). В:Славянска палеография и дипломатика. Т. 1. София, 1980, 72-86.

Попов, Г. Новооткрити химнографрски произведения на Климент Охридски и Константин Преславски.БЕ, 1, 1982, 3-32.

Попов, Г. Химнографското наследство на св. Климент Охридски.КМС, 13. Софиия, 2000, $42-45$.

Попов, Г. Акростих в гимнографическом творчестве учеников Кирилла и Мефодия.

В:Древнерусская литургическая поэзия. XIII Международный съезд славистов (Любляна, 15-21 август 2003). Тематический блок № 14. Доклады. София, 2003, 30-56.

Попов, Г. Проблеми на химнографското творчество на Климент

Охридски.Палеобулгарика, 2, 2008, 3-58.

Сергий.Полный месяцеслов Востока. Том 1: Восточная агиология. Владимир, 1901.

Скабалланович, М.Толковый Типикон, вып. І. Киев, 1910; вып. ІІ. Киев, 1913.

Станчев, К. Проблеми на типологията и терминологията на служебните минеи. В:Пети достоит2003,.... 132-142.

Старобългарска литература. Енциклопедичен речник. Под ред. на Д. Петканова. София, 1992.

Старогръцко-български речник, 3-то изд. София, 1943.

Суботин-Голубовић, Т. Култ светог Николае у средњововној Србији. В:Християнска агиология и народни вярвания. Сборник в чест на ст.н.с. Елена Коцева. София, 2008, 29-37.

Типографрский устав. Устав с кондакарем конца XI - начала XII века. Под ред. на Б. А. Успенский, 3 тома. Москва, 2006.

Тончева, Е. Проблеми на старата българска музика. София, 1975.

Тончева, Е. Преславската керамична плочка с прокименов репертоар от IX-X в. като старобългарски музикален паметник. МХ, 4, 1985, 15-43.

Уханова, Е. В. Древнерусские списки Студийского устава и проблема богослужения

Древней Руси XI-XIII века. B:Liturgische Hymnen nach byzantinischen Ritus2007, ... 74-102. Христова- Шомова, И. Новгородските минеи и Зограсрският миней № 53 (I.e.7). В:Пение мало Георгию2010,.... 117-140.

Чисрлянов, Б. Литургика. София, 1997.

Япова, К. Музика на горните сърца. София, 2007.

Ясіновський, Ю. Візантійська гимнографрія і церковна монодія в украінській рецепціі ранньомодерного часу. Львів, 2011.

, . . , 2008.

. et al. ., 1998.

., 1885.

.. , T. A, 1975; T. B, 1976; Т. Г, 1993. 